NBER WORKING PAPER SERIES

\title{
UNDERSTANDING THE REAL ESTATE \\ PROVISIONS OF TAX REFORM: \\ MOTIVATION AND IMPACT
}

James A. Follian

Patric H. Hendershott

David C. Ling

Working Paper No. 2289

\section{NATIONAL BUREAU OF ECONOMIC RESEARCH 1050 Massachusetts Avenue \\ Cambridge, MA 02138 \\ June 1987}

Presented at the 1987 Mid-Year Meeting of the National Tax AssociationTax Institute of America, May 1987. The research reported here is part of the NBER's research program in Taxation. Any opinions expressed are those of the authors and not those of the National Bureau of Economic Research。 
NBER Working Paper \#2289

June 1987

Understanding the Real Estate Provisions of Tax Reform: Motivation and Impact

\begin{abstract}
Capital investment tax provisions have been changed numerous times in the last decade, with depreciation tax lives shortened in 1981 and lengthened ever since and capital gains taxation reduced in 1978 and 1981 and now increased. The first part of this paper analyzes these changes and attributes a large part of them, including the 1986 Tax Act, to changes in inflation: tax depreciation schedules and capital gains taxation that look reasonable when the tax depreciation base is being eroded at ten percent a year and an overwhelming share of capital gains is pure inflation take on a different appearance when inflation is only four percent.

The remainder of the paper critiques the typical project model used to compute impacts of tax changes on real estate and report simulation results using a modified model.
\end{abstract}

James A. Follain The office of Real Estate Research 430 Commerce West 1206 South 6th street University of Illinois Champaign-Urbana, IL 61820 (217) 244-0952
Patric H. Hendershott Hagerty Hall 1775 College Road The Ohio State University Columbus, Ohio 43210 (614) 292-0552
Mr. David C. Ling Cox School of Business Southern Methodist University Dallas, TX 75275 (214) 692-2785 
The Economic Recovery Tax Act of 1981 (ERTA) contained the most favorable capital investment provisions probably ever enacted: tax lives for all depreciable property were shortened markedly, and capital gains tax rates were lowered sharply owing to the cuts in marginal tax rates. The Tax Reform Act of 1986 more than reverses ERTA: tax depreciation is less generous than before 1981, capital gains tax rates are even higher than before 1978, and new passive loss provisions are being applied to real estate. What brought about this sea change in tax law, and what impact will the change have on real estate? Many explanations for the tax change exist, most relating to political considerations in one way or another, and we certainly would not deny politics, in its widest context, a major role. However, political considerations do not tell the entire story. The rise in inflation and interest rates in the late 1970 s and early 1980 s contributed to the investment provisions of ERTA, and the declines since then influenced the form of the provisions in the 1986 Act. Tax depreciation schedules and capital gains rates that look reasonable when inflation is four percent take on a different hue when the tax depreciation base is being eroded at ten percent a year and an overwhelming share of capital gains is pure inflation.

The "inflation matters" thesis is developed and support for it is provided in the next section. The remainder of the paper discusses the impact of the 1986 Act on real estate. The second section focuses on the methodological issues surrounding many simulation analyses of the effects of tax changes on real estate. The third section discusses the 1ikely impacts of the new law on rents (up), owner costs 
(down), and home ownership (up); the final section summarizes the main conclusions of the paper.

\section{The Apparent Rationale for the Real Estate Provisions}

The key real estate provisions in the Tax Reform Act of 1986 are those pertaining to tax depreciation, capital gains, and passive losses. Changes in tax depreciation lives and capital gains taxation over the last decade follow a pattern that partially explains the provisions in the 1986 tax act. The passive loss rules follow as a logical consequence of not indexing either interest expense or the depreciable basis.

\section{A. Tax Depreciation}

Prior law allowed investors in rental real estate to use the 175 percent declining balance method (with a switch to straight-line in about year nine) and a useful life of 19 years. The new law specifies that the straight-line method be used over a useful life of 27.5 years (31.5 for non-residential structures). This represents the fourth change in the depreciation schedule in the past five years. The Economic Recovery and Tax Act of 1981 (ERTA) shortened useful life from about 30 years to 15. The tax laws of 1984 and 1985 increased useful life to 18 and then to 19 years. The frequency of these changes suggests that future changes are likely. We explore the pattern of past changes in order to better anticipate future changes.

Economists argue that tax depreciation should equal real economic depreciation at replacement cost. This criterion implies a quite low constant annual depreciation rate for structures (less than 4 percent 
per year, Hulton and Wykoff, 1981) but applied to a base indexed to changes in the price level. That is, during inflationary periods, tax depreciation would be backloaded (increase over time), rather than frontloaded as it has always been. Indexation of the basis would result in the present value of tax depreciation being independent of inflation if the discount rate moved one-for-one with the inflation rate.

Legislators have obviously not adopted the economist's explicit indexation recommendation: during the past 15 years tax depreciation has never been less than $61 / 2$ percent in the initial full year and has always declined quickly in subsequent years. However, changes in the useful tax life over the past decade have been negatively correlated with movements in interest rates and inflation. These useful-1ife changes have had the effect of offsetting sharp changes in the present value of the tax saving from tax depreciation allowances generated by the interest rate movements. For example, ERTA reduced useful life to its lowest level at a time when interest rates were at their peak level, and useful life has increased during the 1980s as interest rates have declined. It appears that legislators have adopted an ad hoc strategy of indexation that involves a change in the tax depreciation schedule in response to changes in the inflation/interest rate environment. 1

As evidence of this ad hoc strategy, the present value of the tax saving from tax depreciation allowances is computed for various years during the past decade. We start out with the relatively low inflation/interest rate environment of the middle 1970 s and then 
examine the impact of rising inflation (1980-81), the 1981 tax law response ( 15 versus 30 year useful life), the decrease in inflation and interest rates (1983-84), the 1984 response (15 to 18 year tax life), the further decrease in interest rates/inflation (1986), and finally the Tax Reform Act of 1986. Altogether, seven different combinations of tax law and economic environment are examined. The specific assumptions used to define these tax-economic combinations are listed in the upper half of Table 1. Tax law changes include changes in depreciation policy as well as changes in the marginal tax rate of the marginal investor in real estate. Hendershott, Follain and Ling (HFL 1987) make the case for the 0.45 tax rate (federal plus state and local, after deductibility) under pre-1986 law and 0.36 under the 1986 Act.

The present values of the tax depreciation deductions associated with each tax-economic regime are reported in the lower half of Table 1. The present values are computed under two assumptions: no trading and trading at the end of the tax life of the building. ${ }^{2}$ The higher of the two values has been "bracketed" in the Table. These calculations indicate that trading was suboptimal prior to ERTA and will be suboptimal under the new law. In the interim, trading added from 2 to 5 cents to value per dollar of investment.

Under 1976 law, the tax saving from tax depreciation was 0.267 per dollar of investment, i.e., the present value of tax depreciation allowances multiplied by the appropriate tax rate equalled 26.7 percent of the original basis. When increases/decreases in inflation and interest rates lowered/raised the tax saving relative to 26.7 
percent, the tax depreciation schedule was adjusted to bring the percentage back into line. However, the ERTA of 1981 and the Tax Reform Act of 1986 more than compensated for the earlier increase/ decrease in inflation and interest rates. Thus two cycles for tax depreciation seem to exist, an endogenous response to the inflation/interest-rate cycle and an exogenous "political" cycle. The 1986 Tax Act reflects both of these cycles; depreciation policy under new law is less generous than any tax-economic combination of the past 10 years (probably in the last 50 ).

\section{B. The Passive Loss Provisions}

The 1986 Tax Act contains special provisions for income generated by passive activities, i.e., those in which the taxpayer does not materially participate and rental real estate. The law states that income from passive activities may not be used to offset regular or portfolio income (except, possibly, upon sale of the asset), with exceptions for small landlords and corporations. Under previous law, a substantial portion of real estate returns to many investors during inflationary periods was tax savings generated by using the "paper losses" from real estate to offset taxable income from other activities.

Large passive losses during inflationary periods are a direct consequence of nonindexation of either interest expense or the depreciable basis. Most important is the deductibility of nomina1, rather than real, interest expense. Not only is the inflationary premium in interest rates deductible, but the premium itself is higher 
because of the deductibility (Feldstein 1976). Also significant is the above-discussed endogenous change in tax depreciation when inflation accelerates (greater front-loading of allowances). The imposition of passive loss limits is one way to prevent investors in tax shelters from reducing taxes on their regular income. Figure 1 indicates the amount of losses generated by a particular real estate project during high and low inflation environments under both new law and previous law. Each curve plots losses for different loan-to-value ratios. The lowest two lines indicate the cumulative losses (summation of losses until the year in which positive cash flows are realized) as a percent of investment value for different loan-to-value ratios for the low 1986 inflation/interest-rate environment under new law (lowest) and under old law. The next line indicates how cumulative losses under old law would rise if the economy reverted to the 1981 high inflation/interest-rate environment but Congress did not shorten the tax depreciation schedules (the present value of tax saving from tax depreciation deductions would decline from 0.295 to 0.200 ). The highest line indicates the cumulative losses under old law for both high nominal interest rates and a shorter depreciation schedule (ERTA, which raises the present value to $0.291)$.

The direct effect of inflation upon the amount of passive losses under previous law is striking ( 1 ine 2 vs. line 3 ), and the impact is compounded by an endogenous policy response (line 4). Even all equity projects generated negative cash flow in the early years under this scenario, and negative cash flow would be generated throughout the tax 
life of a project with 80 percent financing. It is not surprising that concerns were raised regarding the efficiency and equity implications of such a system.

Under the new law, passive losses are not projected to be substantial in today's moderate inflation environment. Indeed, passive losses will not be generated for projects with less than 70 percent loan-to-value ratios once rent rises to its equilibrium level (see below). However, passive losses will be generated, even at lower loan-to-value ratios, at higher interest (inflation) rates.

The passive loss limits increase the riskiness of a real estate investment because the government will not continue to share fully the losses of an unsuccessful investment. As a result, rental real estate income earned by proprietors and partnerships will be treated like corporate income, fully taxable if positive, but only banked for future deductions if negative. Investors will require higher rents on real estate investments to compensate for this effective increase in taxation.

\section{Capital Gains Taxation}

After a decade of reductions in the statutory capital gains tax rate (the product of the regular income tax rate and one minus the exclusion), the new law sharply increases this rate. For our assumed marginal investor with a regular tax rate of 0.45 (federal and state) under pre-1986 law and 0.36 under the new law, the gains rate doubles from 0.18 to 0.36 . This contrasts with the declines in 1978 , when the 
exclusion rate was increased from 50 to 60 percent, and in 1981, when regular tax rate cuts lowered the gains rate further to the 0.18 discussed above.

The appropriate tax treatment of capital gains is not obvious. Some would argue that gains should be taxed fully (no exclusion) as they accrue, not upon realization. Others would argue for a favorable treatment, although not necessarily for an exclusion (the deferral advantage of taxation upon realization might be sufficient, at least for long holding periods). Others would opt for the taxation of real gains only, usually accompanied by the deduction of only real interest expense. Our task is not to sort out these issues but only to find a pattern in past legislative behavior regarding capital gains taxation. Changes in the statutory capital gains tax rate over the last decade are consistent with an effort to maintain a constant tax rate on inflationary gains over a holding period of roughly five years. Thus, accelerating inflation in the late 1970s and early 1980s triggered a cut in the gains rate, while the subsequent disinflation induced an increase in the gains rate. ${ }^{3}$ The calculations in the lowest row of Table 1 illustrate this point. The present value of the tax on five years of inflationary gains is computed using the weighted average cost of capital as the discount rate. In the 1976-77 period, the tax is 6.7 percent. The increase in inflation to its 1980 level raises the tax to 8.7 percent, assuming no change in tax rates. The cut in the gains rate from 0.25 to 0.18 offsets the increase in inflation. Similarly, the fall in inflation during the 1980 s cut the 
inflation tax to 3.1 percent by 1986 , and the 1986 increase in the gains tax rate raises the inflation tax back to 6.2 percent.

\section{The Depreciable Real Estate Project Model}

A tool frequently employed to analyze the impact of tax reform upon real estate markets is the "typical project model." This model begins with assumptions regarding the initial loan-to-value ratio, the debt rate, the tax rate of the marginal investor, and the required rate of return on equity. The model computes the minimum rent needed in the first year of operation of the project to equate the net present value of all after-tax cash flows associated with the project (including interest and principal payments on an amortizing mortgage), discounted by the equity rate, to zero. The minimum rent calculation is made with both old and new tax law parameters, and the percentage change in initial rent is the key statistic reported. This section discusses some shortcomings of the project model and our correction of them.

\section{A. Problems with the Project Model}

The major problem with the project model is the treatment of debt and equity. The equity rate is generally based upon what "the industry" seems to be requiring. An economist might specify this rate as the "ten year" tax-exempt rate plus a risk premium. A financial economist would likely employ an after-tax capital asset pricing model where the required after-tax return (e) is the after-tax debt rate

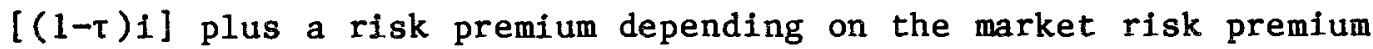
(MRP), the covariance $(\beta)$ of the returns on real estate and the market 
portfolio, the loan-to-value ratio (v), and the tax rate applied to the premium $\left(\tau_{p}\right)$. When the debt has no default risk $(v<0.75 ?)$, the specification is:

$$
e=(1-\tau) i+\left(1-\tau_{p}\right) \frac{\beta}{1-v} \operatorname{MRP}
$$

Equation (1) shows a clear dependence of the required return on leverage (the loan-to-value ratio), tax rates, and the pretax interest rate. ${ }^{4}$ The dependency of the equity rate on leverage does not exist in the project model. Users of the model specifiy an initial $v$ and choose a constant discount rate e for all future cash flows. Because the loan is amortizing and the property value is inflating, the loan-tovalue ratio is falling and thus so must be the required return to equity (Hendershott and Ling, 1986). Setting e at a constant value in the project model involves an internal inconsistency. Moreover, the inconsistency leads to another error. With an assumed constant equity rate, investors are presumed (incorrectly) to be using more and more expensive equity and less and less cheap debt. Investors "solve" this problem by trading properties quickly. In fact, there is little or no need to realign the debt/equity $\mathrm{mix}$ if the equity yield is computed correctly. Indeed, even if a need existed, investors could (1ikely would) realign the debt/equity ratio by refinancing rather than by trading.

The dependency of the equity rate on tax rates and the debt rate is also generally missing in the project model, i.e., e is presumed to be invariant with respect to tax law. 5 
In our model, the cost of capital (or capital budgeting) approach is employed. Debt payments are not included in the cash flows. Rather, a11 nondebt payments are discounted by the weighted average cost of capital,

$$
\text { WACC }=v(1-\tau) i+(1-v) e,
$$

to obtain the initial minimum rent substituting (1) into (2) produces

$$
\text { WACC }=(1-\tau) i+\left(1-\tau_{p}\right) \beta \cdot \operatorname{MRP}
$$

Note that the weighted average cost of capital is independent of the loan-to-value ratio. Thus the initial minimum rent in this model is independent of leverage. 6

Using (2') requires specification of $\beta \cdot M R P$ and $\tau_{p}$, nontrivial tasks. Fortunately, some information is available on $\tau_{p}$ and MRP, and $B$ can be chosen so that the computed $e$ is consistent with what the industry seemed to be requiring under prereform law at the interest rates then existing. With this spectication, e can be recomputed in an internally consistent manner to reflect the new law. In the ca1culations below, $i=0.09, \pi=0.045$ and the tax rate on the risk premium is set equal to one-third the tax rate on ordinary income plus two-thirds the effective capital gains tax rate. This latter rate equals one-half the statutory rate, the one-half reflecting the value of deferra1. Fina1ly, we set $\beta \cdot M R P=0.03$, a specification that is consistent with $\beta=0.5$ and $\operatorname{MRP}=0.06 .^{7}$ 
B. Project Mode1 Versus General Equilibrium Models

Common practice these days is to criticize the "partial equilibrium" project model in favor of a general equilibrium (GE) analysis (Gravelle 1986). This practice is badly misfocused. To see this, consider the gains and losses associated with the use of a GE model that are relevant to the impact of tax reform on rents. The gains from a GE model include the change in the level of debt rates and possibly other market parameters, such as the market risk premium affecting the required return on equity. The losses are the failure to capture the impacts of industry specific tax changes. For depreciable real estate, these include the capitalization of construction period interest and taxes (rather than the previous 10-year write off), changes in the gains from trading (both the higher capital gains tax rate and lengthening of tax depreciation write offs reduce the gains), and less favorable treatment of interest expense (passive loss rules, interest limitations, and at-risk rules). Not only is the latter list longer than the former, but, more importantly, GE responses can be easily factored into the project model: if GE considerations led one to think interest rates will decline by a percentage point, a one point decline could be used in the calculation.

The practical choice, then, is whether to use the corrected project model (the cost of capital variant) with GE responses incorporated or to use GE models that ignore much interesting nitty gritty. In our view the former will produce better estimates of tax reform's impact than the latter; consequently, this procedure is followed here. 
Actually, the GE models are generally less valuable than the above discussion indicates. Take the impact of the Tax Act on interest rates. The Act will certainly lower the level of interest rates because the Act has a negative direct impact on the demands for all capital goods. But the extent of the decline depends on the interest elasticity of domestic and foreign saving, elasticities about which we are highly uncertain. To accept the GE results from a particular model is to accept a wide range of assumptions, many of which are quite tenuous and others of which are not stated. ${ }^{8}$

In the analysis below, a one percentage point decline in interest rates is generally assumed, somewhat less than a fixed capital stock or constant saving model would imply (HFL, 1987). The WACC response is calculated from $\left(2^{\prime}\right)$.

\section{Some Estimated Impacts}

We compute percentage changes in rents, in the annual rental cost of owner housing, and in the ratio of these rents, the latter being relevant to the tenure choice decision. Our primary emphasis is on the rent impact; estimates of the impact on costs of owner housing were presented in HFL (1987) and are therefore only summarized here.

\section{A. Equilibrium Rent Levels}

The equilibrium level of rent under the Tax Act must increase to replace the reduced tax benefits. Only then will investors in real estate earn a rate of return comparable to that on other investments of similar risk. We compute estimates of the likely rent increase for 
residential properties under alternative assumptions regarding both the tax rate of the marginal investor in real estate and the size of the interest rate decline.

With no change in the interest rate and a 45 percent marginal tax rate for the marginal investor, residential rents will increase by 13 percent; with a 52 percent marginal rate, the rent increase is 21 percent. If a percentage point decline in interest rates is factored into the analysis, the required residential rent increase is reduced from 13 percent to 6 percent for the 45 percent tax-rate investor and from 21 percent to 13 percent for the 52 percent investor.

of these estimates, we consider the 6 percent rent increase, or something only slightly higher, to be most likely. We believe the marginal investor under old law to have been in the 45 percent tax bracket (federal plus state and local, with deductibility), and we think that interest rates have already declined by a percentage point because of the Tax Act (see HFL 1987 for a discussion of these points). A slightly higher percentage rent increase, say 10 percent, might occur for the two reasons discussed above: the importance of the relatively certain tax depreciation component of the return to real estate will decline vis-a-vis the less certain net operating income component and real estate losses will no longer be deductible against nonpassive income.

The timing of the increase in rents depends upon the local rental market. Following our earlier analysis (HFL 1987), a three-year adjustment is reasonable in fast growing markets, while up to eight 
years is reasonable in slow growing areas with vacancy rates 10 percentage points above equilibrium levels. Moreover, the extent of value declines depends on how much and how long rents are expected to be below their equilibrium level. For a 10 percent increase in equilibrium rents, the percentage declines in value for our two extreme rent-adjustment assumptions are one and seven (HFL 1987).

Gravelle (1986) contends that a negative impact of the 1986 Tax Act on depreciable real estate is implausible because equipment is clearly the type of capital hardest hit. We agreed in our earlier paper that investments losing tax credits (including real estate historic and rehabilitation projects) would be most adversely affected (HFL 1987, p. 75$).{ }^{9}$ But so what? As noted above, the new law is anti-investment across the board. Every type of capital good (except possibly low income housing) suffers a direct negative impact from the Act. In a world with open capital markets, all types of U.S. capital goods could contract as capital flows abroad. With closed capital markets, the negative impact on equipment needs to be offset by a positive impact elsewhere, but that offset need not be depreciable real estate. Owner-occupied housing, which is a larger component of the total capital stock than is equipment, is certainly the most relatively favored component of capital (see below). Thus, even with a fixed capital stock, there is room for a negative impact on depreciable real estate, i.e., a rise in rents. 
B. Owner-Occupied Housing and Home Ownership

The 1986 Tax Act does not directly alter any of the favorable tax provisions granted owner-occupied housing; imputed rents are still not taxed, capital gains are taxed (if at all) with a long deferral, and these advantages are still available to debt-financed, as well as equity-financed, housing (interest remains deductible on two houses). Nonetheless, the Tax Act affects the after-tax cost of owner housing through two channels. First, the tax rates at which households deduct housing costs are reduced. Second, the pretax level of interest rates will be lower. In addition, the net changes in owner costs in conjunction with the rise in market rents will probably alter the aggregate home ownership rate. This section briefly summarizes our previously published results regarding these effects.

As with rental housing, the cost of owner-occupied housing depends upon the cost of capital, property taxes, real economic depreciation, expected appreciation, and tax savings. Two measures of this cost are relevant: the average cost, which influences the tenure choice decision; and the marginal cost, which affects the quantity demanded by homeowners. If interest rates are a percentage point lower, as we contend, then households with incomes below about $\$ 30,000$ will experience a 10 percent decrease in marginal housing costs; households with incomes above about $\$ 130,000$ will face a 5 percent increase; and the change for other households will be negligible. Average housing costs will also decrease slightly for households with incomes below approximately $\$ 60,000$; however, households with incomes above about 
$\$ 120,000$ will experience a 5 percent increase in costs. These calculations suggest that significant changes in the quantity of owneroccupied housing demanded, and thus in the value of existing houses, will be limited to households and houses at the extremes of the income and value spectrums. 10

Another implication pertains to the rent-own decision of households. The average cost calculations suggest that with an interest rate decline and no change in rents, ownership is modestly more attractive for households with incomes below about $\$ 60,000$ and slightly less attractive for higher-income households. With a 10 percent rise in rents, all currently renting households will find ownership more attractive than under the old law. The magnitude of the impact on the aggregate ownership rate is uncertain. With a high assumed elasticity of ownership with respect to tenure prices, the rise could eventually be as much as three percentage points. With a low elasticity, the rise would be less than one point (Haurin, Hendershott and Ling, 1987).

\section{Summary}

During the past decade changes in tax depreciation allowances and in the statutory capital gains tax rate have followed a pattern that provides both a rationale for the major real estate provisions of the 1986 Tax and a basis for anticipating future tax changes. The common thread through the hypothesized rationale is inflation and how the tax system is adjusted for it. If the tax system had been fully indexed (depreciation basis, interest expense, and capital gains), little need 
would have existed for the real estate provisions of the 1986 Tax Act. The present value of tax savings from depreciation allowances would not have increased and that of taxes on inflationary capital gains would not have decreased in response to the declines in inflation and interest rates since 1981 ; thus, offsetting legislation would have been unnecessary (or less necessary). Moreover, the passive loss rules would be unnecessary with a fully indexed system because interest expense and depreciation deductions would be far less during inflationary periods. Finally, this analysis predicts a cut in the gains tax rate (a return of the exclusion) and a shortening of depreciation tax lives if inflation should rebound.

In contrast to the conventional wisdom, the 1986 tax act is unlikely to discourage real estate activity in the aggregate. Within the broad aggregate, however, widely different effects are to be expected. Depreciable real estate will be slightly disfavored; a 6 to 10 percent increase in the equilibrium level of rents is likely. Historic and regular rehabilitation projects will be more negatively affected. In contrast, owner-occupied housing, by far the largest component of real estate, is favored, both directly by an interest rate decline and Indirectly by the increase in rents. Home ownership should rise somewhat, and the quantity of houses demanded and value of existing houses should increase slightly, except at the very high end of the income and house value distributions. 
FOOTNOTES

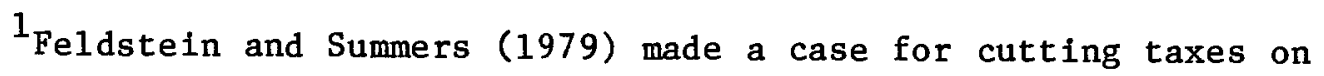
capital income to of fet the increase in inflation.

2 The weighted average cost of capital is used as the discount rate. This average is defined precisely in the text below.

3 Feldstein and Slemrod (1979) make a case for low (or zero) taxation of inflationary gains.

${ }^{4}$ of course, if $(1-t) i$ equals the tax-exempt rate and the risk premium is measured as the second term in (1), the economist and financial economist are in full agreement.

${ }^{5}$ Another problem with the project model is the high discount rate (e) applied to tax depreciation allowances which are less risky than net operating income. Using $e$ as the discount rate will generally overstate the negative impact (increase in initial rent) of a less generous tax depreciation schedule because the more distant deductions are discounted too severely (Hendershott and Ling, 1986).

${ }^{6}$ Gravelle's (1986) calculations of initial rent increases that vary with the leverage ratio are the result of not allowing $e$ to vary with $v$ and thus do not provide useful information.

Although initial rents are independent of the leverage used by the marginal investor, the expected returns to investors in tax brackets above that of the marginal investor increase with leverage; when excess returns (expected above required) are available, leverage pays. 
${ }^{7}$ Inflation is well understood to alter the cost of capital under a wide variety of tax regimes, including old law and the Tax Reform Act of 1986 (see Hendershott 1987 and Henderson 1986, for example). More specifically, inflation favors rental housing, although by less under new law than under old. To illustrate this point, a number of simulations were run. An increase in expected inflation from $4 \frac{1}{2}$ to 9 percent would, under old law, eventually lower initial rents by 13 to 24 percent, the smaller figure being based on interest rates rising more than one-for-one with expected inflation (both calculations incorporate an "endogenous" shortening of tax depreciation lives to hold the present value of the depreciation tax saving constant). Under the 1986 Tax Act, the percentage decreases are about halved.

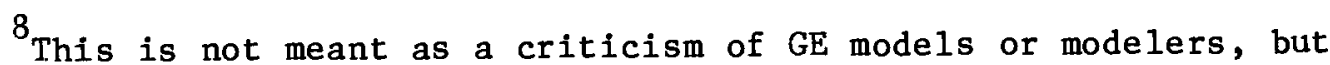
rather of the uncritical acceptance of their simulation results. ${ }^{9}$ This point is widely understood (see Henderson 1986 and Hendershott 1987, for example).

${ }^{10}$ All the calculations are for "typical" married couples with two dependents. Because tax rates of "other" household heads are reduced relatively more, the increase in their costs of owner housing is somewhat greater. 


\section{REFERENCES}

Feldstein, Martin, "Inflation, Income Taxes, and the Rate of Interest:

A Theoretical Analysis," American Economic Review, 66, pp. 809-20, December 1976.

Feldstein, Martin and Joel Slemrod, "Inflation and the Excess Taxation of Capital Gains on Corporate Stock," National Tax Journal, 31, pp. 107-88, June 1979 .

Feldstein, Martin and Lawrence Summers, "Inflation and the Taxation of Capital Income in the Corporate Sector," National Tax Journal, 32, pp. 445-70, December 1979.

Gravelle, Jane, "The Effect of the Passive Loss Restriction in the Tax Reform Act on Investment in Real Estate," unpublished manuscript, 1986.

Haurin, Donald R., Patric H. Hendershott and David C. Ling, "Home Ownership Rates of Married Couples: An Econometric Analysis," paper presented at the Midyear Meetings of the American Real Estate and Urban Economics Association, May 1987.

Hendershott, Patric H., "Tax Reform and the Slope of the Playing Field," in Taxes and Capital Formation, ed. Martin Feldstein, University of Chicago Press, 1987.

Hendershott, Patric H., James R. Follain, and David C. Ling, "Effects on Real Estate," in Tax Reform and the U.S. Economy, ed. Joseph A. Pechman, Brookings Institute, Washington, D.C., pp. 71-94, 1987. 
Hendershott, Patric H. and David C. Ling, "Likely Impacts of the Administration Proposal and the House Bil1," in Tax Reform and

Real Estate, ed. James R. Follain, The Urban Institute, Washington, D.C., pp. 87-112, 1986.

Henderson, Yolanda K., "Lessons from Federal Reform of Business Taxes," New England Economic Review, Federal Reserve Bank of Boston, Nov./Dec. 1986.

Hulten, Charles R. and Frank C. Wykoff, "The Measurement of Economic Depreciation," in Depreciation, Inflation, and the Taxation of Income from Capital, ed. Charles R. Hulten, Urban Institute Press, Washington, D.C., pp. 81-129, 1981. 


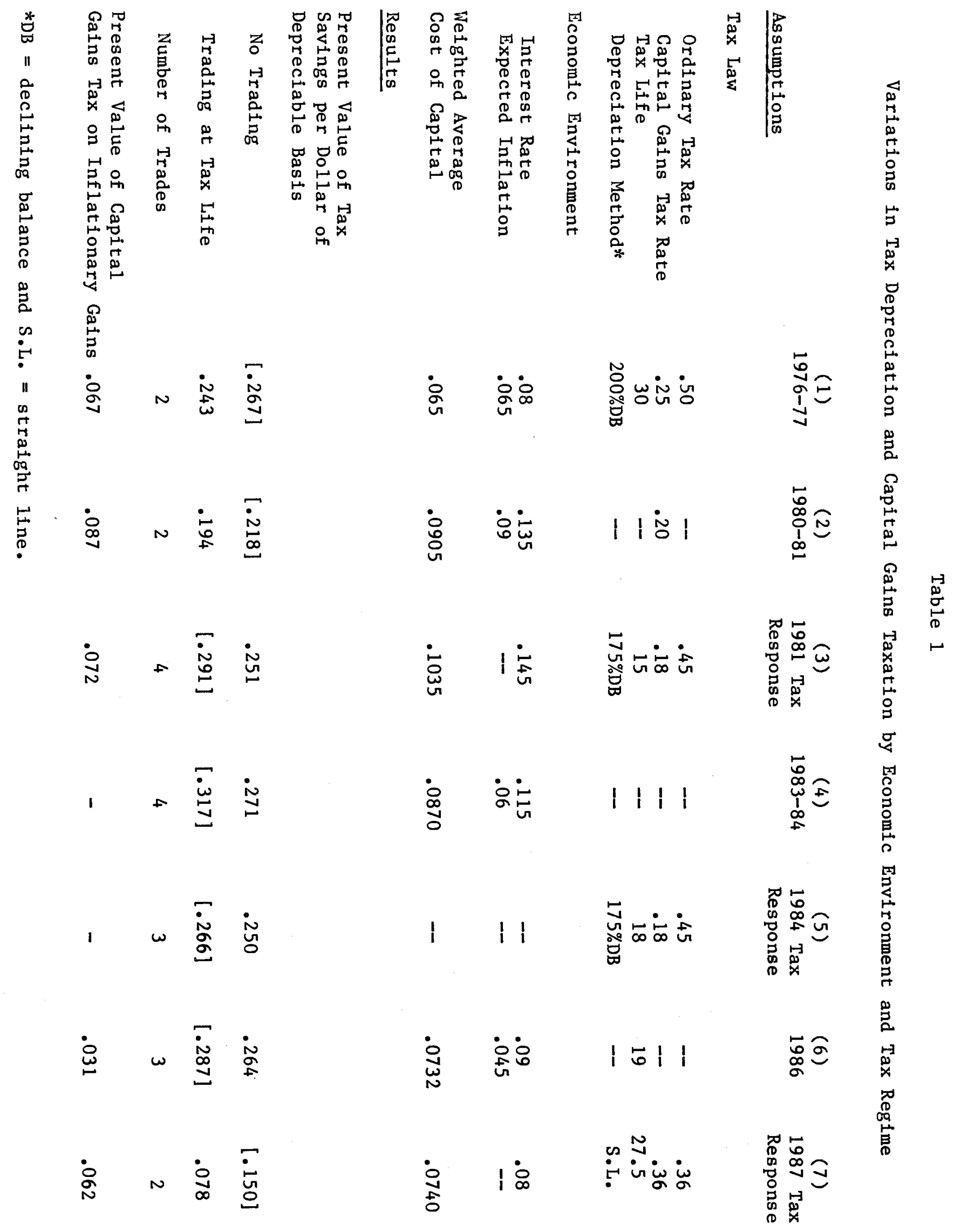

